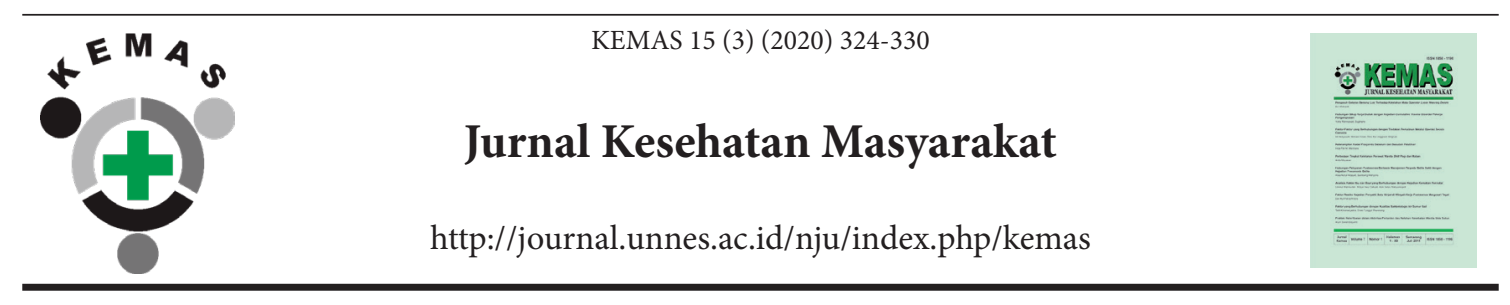

\title{
The Impact of Bina Keluarga Lansia program on the Quality of Life of Elderly in Sleman, Yogyakarta
}

\author{
Teguh Kristian Perdamaian ${ }^{凶}$, Widya Christine Manus, Septian Dewi Periska, and Ni Nengah \\ Putri Ayu Steffiasih
}

Fakultas Kedokteran Universitas Kristen Duta Wacana, Yogyakarta

\section{Article Info \\ Article History: \\ Submitted May 2019 \\ Accepted October 2019 \\ Published March 2020 \\ Keywords: \\ Elderly, Community Health, \\ Bina Keluarga Lansia, \\ Quality of Life, Yogyakarta \\ DOI \\ https://doi.org/10.15294/ \\ kemas.v15i3.19104}

\begin{abstract}
Indonesian government, through BKKBN, has joined to promote healthy life in the elderly in the community. Bina Keluarga Lansia (BKL) programme was established to fulfil elderly need through a family-based approach. This study is aimed to evaluate the programme with the examination of the quality of life of its members, including the elderly and their family member. We used a cross-sectional method using WHO-QOL BREF questionnaire to assess the quality of life and another questionnaire to enlist the involvement on the BKL activities. This study was conducted in 2018, at four BKL groups across Sleman Regency. Further analysis was conducted with gaussian mix models to adjust for the cluster effect from sampling method. Our 103 respondents with 68 family members and 35 elderly generally have a good quality of life on four dimensions of WHO-QOL BREF. We found that BKL activities statistically significant associated with better QoL, especially in Social Domain and Psychological Domain. Activities that were specifically associated with better QoL was health education on elderly resilience and art/music activities. Other activities that show borderline association was business activities. BKL programme has shown an association with better QoL, thus any successful activities should be maintained or improved, and other less influential activities should be reviewed and customised with local needs.
\end{abstract}

\section{Introduction}

Indonesia is the fourth-largest nation in the world, with a projected increase in the elderly population in the upcoming decades. In 2017, there were $9.03 \%$ population above 60 years old in Indonesia (Pusdatin Kemenkes RI., 2018). The elderly population, due to the aging process, possesses health and social burden individually and public-wide. Decreased daily function hindered older persons to be independent and participate in any social activities (Asthana et al., 2017). In a larger context, the elderly patients account for a huge portion of national health insurance claims, and further financial dependency on productive citizens. Therefore, this projected increment of the elderly population should be followed by active interventions by the government in providing adequate healthcare, social welfare support, as well as the production environment to promote independence.

One of the government efforts was 'Bina Keluarga Lansia (BKL)' initiated by BKKBN (Badan Kependudukan dan Keluarga Berencana Nasional [Indonesian National Body for Demography and Family Planning]), with family-based empowerment approach to improve family's knowledge and practice in providing productive and healthy milieu for their elderly members. The main activities are family and community capacity building in family resilience, general elderly health and economical productive activity. Each BKL unit would have their own development and 
range activities according to local resources and wisdom, such as traditional music groups, routine physical exercise, or smallscale farming. The motivation of the BKL groups will seasonally increase preparing for the annual competition of BKL throughout Indonesia (BKKBN, 2011, BKKBN, 2017). In its application, BKL has been a larger community-based vessel which accommodates not only BKKBN programmes, but also health promotion programmes from Department of Health and long-term care activities and social support for neglected elderly from Department of Social Welfare.

Yogyakarta is placed first as the province with the highest prevalence of elderly (13,81\%) in 2017 (Pusdatin Kemenkes RI., 2018). There are 663 BKL units since its initiation in 2012, spread out in 1 city and 4 districts. Some of the BKL units are well known as the best BKL units in a national competition (BKKBN, 2011, $B K K B N$, 2017). These units have developed into a large community with various activities. Nevertheless, until now there is no scientific evidence regarding the impact of BKL units on its members, especially in fulfilling the initial purpose, which is family resilience. We believe that the quality of life of BKL members is an appropriate measurement of its impact, especially regarding health and social interactions, which are the most important part for living the rest of their elderly life. This study measured the quality of life of the elderly and family members of some BKL units in Sleman Regency, Yogyakarta, in order to assess the impacts of BKL activities on family resilience.

Method

This is a cross-sectional study involving the family and elderly members of four BKL units in Sleman Regency, Yogyakarta. These units were picked with a stratified cluster sampling method, which considered the BKL unit grading provided by the BKKBN. The units are Mugi Waras group from Sumbersari Village, Sekar Tanjung group from Margodadi Village, Wijaya Kusuma from Tridadi Village, and Melati group from Bangunkerto Village.

There were initially 112 respondents, which were 68 family members and 44 elderly. We further excluded 9 elderly because of cognitive impairment assessed with clock drawing task (based on the 20-point score by Mendez et al. (1992)) thus final respondents are 103 , comprised of 68 family members and 35 elderly.

The questionnaire given to the participants consisted of two parts, the first is a description of BKL activities and the second is the quality of life section. The BKL activities are described into the frequency of participation, and the types of activities involved (includes capacity building in elderly resilience, capacity building in general health topics, general health check, business and productivity, art and music, religious activities, and sports) in the past 6 months. We used an Indonesian version of WHO-QoL BREF to assess the quality of life of BKL members in four dimensions, which are physical, social, psychological, and environmental. This version has been validated previously in other studies. WHO-QoL BREF is proven valid and reliable to measure the quality of life of all ages.

The participant's characteristics, BKL activities, and Quality of Life are described in tables and pictures. Gaussian mix model is used to address the clustering effects of each BKL units, and further, assess the relationship between each Quality of Life domain and BKL activities. Each QoL domain will be treated as a dependent variable, whereas age, sex, and BKL activities will be treated as a fixed-effect variable. The univariable model used each BKL activity for each model, and multivariable model used all of BKL activities in one model. BKL units ID will be treated as random effect variables. Furthermore, we tested the multivariate effects of four outcomes, which are four domains of QoL, using Pillai test.

\section{Result and Discussion}

Table 1 described the baseline characteristics of our participants. In addition, around $58 \%$ of the participants is a housewife, and $3,6 \%$ lives alone. This finding shows that most participants are women and don't have a previous occupational history. Men participation is considered very low, as the latest census in 2018 reported that there are $47,64 \%$ male elderly and 52,35\% female elderly in Sleman Regency One study comparing Japan and Korean elderly explained that the lack of men participation could be related with their 
Table 1. The Baseline characteristics of respondents from 4 BKL groups across Sleman Regency, Yogyakarta, year 2018

\begin{tabular}{llll}
\hline & Family member $(\mathrm{n}=68)$ & Elderly $(\mathrm{n}=35)$ & Total $(\mathrm{n}=103)$ \\
\hline $\begin{array}{l}\text { Age (years) } \\
\text { Mean } \pm \text { SD }\end{array}$ & $43.99 \pm 9.543$ & $65.46 \pm 4.565$ & $51.28 \pm 13.085$ \\
\hline Sex (n(\%)) & & \\
Female & $66(97.06 \%)$ & $26(74,29 \%)$ & $92(89.32 \%)$ \\
Male & $2(2.94 \%)$ & $9(25.71 \%)$ & $11(10.68 \%)$ \\
\hline BKL Unit (n(\%)) & & \\
Mugi Waras & $20(29.41 \%)$ & $11(31.43 \%)$ & $31(30.10 \%)$ \\
Sekar Tanjung & $18(26.47 \%)$ & $4(11.43 \%)$ & $22(21.36 \%)$ \\
Wijaya Kusuma & $15(22.06 \%)$ & $14(40.00 \%)$ & $29(28.16 \%)$ \\
Melati & $15(22.06 \%)$ & $6(17.14 \%)$ & $21(20.39 \%)$ \\
\hline BKL Activities (n(\%)) & & & \\
Capacity building 1 & $54(79.4 \%)$ & $32(91.4 \%)$ & $86(83.50 \%)$ \\
Capacity building 2 & $29(42.6 \%)$ & $29(82.9 \%)$ & $58(56.31 \%)$ \\
General health check & $49(72.1 \%)$ & $34(97.1 \%)$ & $83(80.58 \%)$ \\
Business & $26(38.2 \%)$ & $17(48.6 \%)$ & $43(41.75 \%)$ \\
Art and music & $11(16.2 \%)$ & $15(42.9 \%)$ & $26(25.24 \%)$ \\
Sport & $34(50.0 \%)$ & $8(22.9 \%)$ & $42(40.78 \%)$ \\
Religious activities & $22(32.4 \%)$ & $14(40.0 \%)$ & $36(34.95 \%)$ \\
\hline QoL Score (Mean \pm SD) & & & \\
Physical & $71.53 \pm 10.899$ & $71.43 \pm 10.322$ & $71.49 \pm 10.656$ \\
Social & $76.41 \pm 12.209$ & $75.36 \pm 11.179$ & $76.05 \pm 11.824$ \\
Psychological & $69.98 \pm 12.144$ & $79.76 \pm 12.987$ & $73.30 \pm 13.220$ \\
Environmental & $72.89 \pm 9.138$ & $74.66 \pm 11.266$ & $73.49 \pm 9.893$ \\
\hline Source: Primary Data 2018 & &
\end{tabular}

Source: Primary Data, 2018

occupation and loneliness, moreover social participation could be recreational or passive participation, which do not actively contribute to the community (Katagiri and Kim, 2018).

The most common BKL activities joined by the members are capacity building meetings and general health checks (through Posyandu). These activities are organized by cadres from each village administrative office and trained by BKKBN and the Department of Health. Meanwhile, self-developed activities such as art and music, and religious activities has the lowest attendance. The top-down approach from the government, with a focus on national targets on elderly health and social welfare, has been well-maintained related to continuous funding. However, the bottom-up approach with community-based activities, rely mainly on their own economy or external supports other than the government. The Mugi Waras group has received much of those external supports, thus they could develop many local activities, such as traditional music, small-scale farming, and village library. The influence of government control through funding which diminished community initiatives has been well described by (Carey and Braunack-Mayer, 2009) on a community-based organization in Australia.

The quality of life of the BKL's members on average is higher than the pre-determined cut-off $(50 \%)$ of good QoL. We could see that there is no substantial difference between elderly and family groups in the three domains of QoL, where there is a quite wide difference in psychological domains. It is apparent that family members have much lower QoL on psychological domains compared to the elderly group (69.96 vs 79.76). Although not further studied among our participants, we believed that the high QoL score on the psychology domain relates to the positive attitude of aging. 
Table 2. The WHO-QoL BREF score of respondents from 4 BKL groups across Sleman Regency according to the BKL activities and QoL domain, year $2018(\mathrm{n}=103)$

\begin{tabular}{lllll}
\hline & Physical & Psychological & Social & Environmental \\
\hline Capacity building 1 & & & & \\
Active & $71.64 \pm 10.486$ & $77.13 \pm 10.804$ & $74.61 \pm 12.713$ & $73.76 \pm 10.058$ \\
Not Active & $70.79 \pm 11.794$ & $70.59 \pm 15.272$ & $66.67 \pm 14.129$ & $72.09 \pm 9.161$ \\
\hline Capacity building 2 & & & & \\
Active & $70.63 \pm 10.973$ & $76.44 \pm 11.902$ & $69.44 \pm 11.650$ & $73.07 \pm 11.291$ \\
Not Active & $72.62 \pm 10.244$ & $75.56 \pm 11.839$ & $76.29 \pm 13.679$ & $74.03 \pm 7.822$ \\
\hline General health & & & & \\
check & $70.99 \pm 10.836$ & $75.60 \pm 12.349$ & $73.49 \pm 13.471$ & $72.82 \pm 9.650$ \\
Active & $73.57 \pm 9.859$ & $77.92 \pm 9.376$ & $72.50 \pm 12.419$ & $76.25 \pm 10.653$ \\
Not Active & & & & \\
\hline Business & & & & \\
Active & $73.75 \pm 11.791$ & $73.934 \pm 12.862$ & $75.00 \pm 14.885$ & $73.85 \_09.840$ \\
Not Active & $69.88 \pm 9.537$ & $77.569 \pm 10.879$ & $72.08 \pm 11.867$ & $73.23 \pm 10.005$ \\
\hline Art and music & & & & \\
Active & $72.94 \pm 9.645$ & $76.89 \pm 12.363$ & $78.85 \pm 12.299$ & $73.94 \pm 11.255$ \\
Not Active & $71.01 \pm 10.992$ & $73.56 \pm 9.856$ & $71.43 \pm 13.067$ & $73.34 \pm 9.465$ \\
\hline Sport & & & & \\
Active & $70.92 \pm 11.115$ & $76.98 \pm 10.741$ & $71.83 \pm 13.008$ & $71.28 \pm 8.432$ \\
Not Active & $71.89 \pm 10.402$ & $75.40 \pm 12.562$ & $74.32 \pm 13.376$ & $75.007 \pm 10.584$ \\
\hline Religious & & & & \\
Active & $70.24 \pm 10.351$ & $77.08 \pm 12.539$ & $74.07 \pm 11.748$ & $72.14 \pm 10.253$ \\
Not Active & $72.17 \pm 10.832$ & $75.49 \pm 11.480$ & $72.89 \pm 14.015$ & $74.21 \pm 9.694$ \\
\hline Source Primary Data & 2018 & & &
\end{tabular}

Source: Primary Data, 2018

A positive attitude is related to optimism and self-esteem, which influenced by long-life experience, intuition, and religiosity (Jimenez et al., 2017). On the contrary, negativity towards aging would increase the risk of frailty and cognitive deterioration (Robertson and Kenny, 2016).

Especially in the elderly, our findings suggest that participants of BKL have higher QoL compared to other studies in different areas. Yuliati et al. (2014) discovered that 105 community-dwelling elderly with unknown community-based activities in Jember, East Java has QoL average lower than $60 \%$ on a physical, social, and environmental domain. A similar finding is also found in a study in Puducherry, India on 300 community-dwelling elderly (Kumar et al., 2014).

Table 2 shows a detail description of QoL score in each domain related to the activities involved and Table 3 shows the corresponding results of statistical analyses using gaussian mix models. In the univariable analyses, participants who actively attend capacity building on elderly resilience (Capacity building 1) have statistically significant higher QoL in psychological domain (77.13 vs $70.59 ; \mathrm{AIC}=802.19, \mathrm{~b}=7.11, \mathrm{p}=$ $0,027)$. Meanwhile, members who actively join art and music activities tend to have a 6.01 higher QoL score on social domain, compared to members who do not join (78.85 vs. 71.43 ; $\mathrm{AIC}=819.04, \mathrm{~b}=6.01, \mathrm{p}=0,047)$. Nevertheless, business activity shows a borderline significant positive association with physical domain (73.75 vs $69.88 ; \mathrm{AIC}=783.27, \mathrm{~b}=4.71, \mathrm{p}=$ $0,059)$, and general health check that have borderline significant negative association with environmental domain (72.82 vs 76.25 ; $\mathrm{AIC}=762.38, \mathrm{~b}=4.71, \mathrm{p}=0,059)$. Further consideration of the multivariate nature of QoL score, the Pillai test (Table 3 (b)) shows that no significant association between the 
Table 3 The results of univariate gaussian mixed model with BKL activities as independent variable and QoL Domain as dependent variable from 4 BKL groups across Sleman Regency, Yogyakarta, Year 2018.

(a). The results of univariable gaussian mixed model, adjusted with participant age and sex $(\mathrm{n}=103)$

\begin{tabular}{|c|c|c|c|c|c|c|c|c|c|c|c|c|}
\hline \multirow{3}{*}{$\begin{array}{l}\text { BKL } \\
\text { Activities }\end{array}$} & \multicolumn{12}{|c|}{ QoL Domain } \\
\hline & \multicolumn{3}{|c|}{ Physical } & \multicolumn{3}{|c|}{ Psychological } & \multicolumn{2}{|l|}{ Social } & \multicolumn{4}{|c|}{ Environmental } \\
\hline & AIC & $\mathrm{b}$ & $\mathrm{p}$ & AIC & b & $\mathrm{p}$ & AIC & b & $\mathrm{p}$ & AIC & b & $\mathrm{p}$ \\
\hline $\begin{array}{l}\text { Capacity } \\
\text { building } 1\end{array}$ & 786.26 & 2.55 & 0.388 & 802.19 & 7.11 & 0.027 & 820.73 & 5.28 & 0.128 & 766.15 & 0.49 & 0.852 \\
\hline $\begin{array}{l}\text { Capacity } \\
\text { building } 2\end{array}$ & 786.64 & -1.48 & 0.555 & 806.93 & 1.62 & 0.560 & 821.16 & 3.89 & 0.168 & 764.68 & -2.56 & 0.231 \\
\hline $\begin{array}{l}\text { General } \\
\text { health check }\end{array}$ & 786.37 & -2.25 & 0.438 & 806.73 & -2.33 & 0.467 & 822.08 & -3.49 & 0.312 & 762.38 & -4.96 & 0.057 \\
\hline Business & 783.27 & 4.71 & 0.059 & 806.38 & -2.71 & 0.328 & 822.34 & 2.25 & 0.379 & 765.99 & 0.84 & 0.664 \\
\hline $\begin{array}{l}\text { Art and } \\
\text { music }\end{array}$ & 784.92 & 3.65 & 0.157 & 806.45 & -2.54 & 0.373 & 819.04 & 6.01 & 0.047 & 765.97 & 1.06 & 0.649 \\
\hline Sport & 786.94 & -0.57 & 0.804 & 806.19 & 2.56 & 0.308 & 823.07 & 0.75 & 0.782 & 764.85 & -2.33 & 0.259 \\
\hline Religious & 786.90 & -0.77 & 0.753 & 806.93 & 1.60 & 0.560 & 823.08 & 0.68 & 0.796 & 765.35 & -1.79 & 0.372 \\
\hline
\end{tabular}

Note: AIC: Akaike Information Criteria, b: value of slope, p: p-value

Source: Primary Data, 2018

(b). The multivariate test (Pillai test) of univariate gaussian mixed model, adjusted with participant age and sex $(n=103)$

\begin{tabular}{lll}
\hline & \multicolumn{2}{l}{ Pillai test } \\
\cline { 2 - 3 } & $\mathrm{c}^{2}(\mathrm{df})$ & $\mathrm{p}$ \\
\hline Capacity building 1 & $0.7813(1)$ & 0.3768 \\
Capacity building 2 & $0.3655(1)$ & 0.5454 \\
General health check & $0.6924(1)$ & 0.4276 \\
Business & $3.8082(1)$ & 0.0510 \\
Art and music & $2.1221(1)$ & 0.1452 \\
Sport & $0.0643(1)$ & 0.7998 \\
Religious & $0.1033(1)$ & 0.7479 \\
\hline
\end{tabular}

Source: Primary Data, 2018

each BKL activities and QoL score, except for borderline association of business activities with QoL, specifically with the physical domain. Further multivariable analysis (Table 4) showed the significant association between capacity building on elderly resilience with psychological wellbeing $(\mathrm{AIC}=809.3, \mathrm{~b}=7.49$, $\mathrm{p}=0.029)$, where respondent who joined the activity tend to have 7.49 higher QoL score on psychology domain, compared with other who did not join.

The concept of elderly resilience adopted by BKKBN comprises of seven dimensions, which are spiritual resilience, physical resilience, emotional resilience, social resilience, cognitive resilience, environmental resilience, and financial and occupational resilience (BKKBN, 2017). The capacity building on spiritual, cognitive and emotional resilience is most likely to associate with the psychological domains of quality of life. Stevens (2016) argued that spirituality or mindfulness would help to achieve reconciliation and peace in later life which enables older people 
Table 4 . The results of multivariate gaussian mixed model with BKL activities as independent variable adjusted with participant age and sex and QoL Domain as dependent variable from 4 BKL groups across Sleman Regency, Yogyakarta, Year 2018 (n=103)

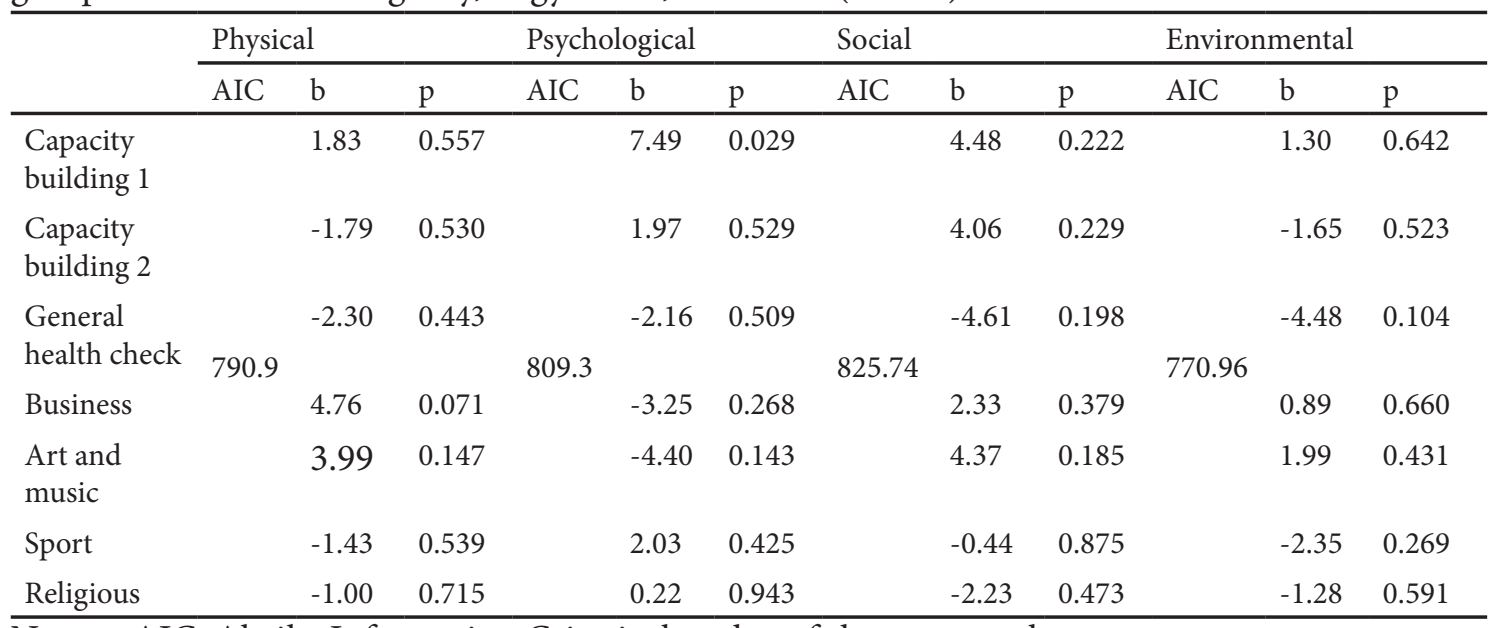

Note: AIC: Akaike Information Criteria, b: value of slope, p: p-value

Source: Primary Data, 2018

to accept and adapt to physical and cognitive deterioration. In addition, Chaves and Gil's (2015)) findings agreed that spirituality would help the elderly in the capacity to bear physical limitations and difficulties in living daily life. Emotional resilience could be simplified with the 'level of happiness', in which many studies reported the association between happiness and psychological well-being (Holahan et al., 2008, Smith and Hollinger-Smith, 2015). Therefore, the findings from this study are relevant to previous research, which indirectly shows the association between capacity building on elderly resilience, especially in spiritual and emotional aspects.

The result of this study mainly showed the influence of BKL activities on the psychological well-being of the elderly and their family caregiver. The similar result was found by Salomoni et al. (2018) with an improvement of psychological QoL among females (9.41 $\%)$ and male $(9.75 \%)$ Iranian elderly after conducting public health intervention, which included capacity building sessions on selfconfidence and self-esteem topics. In addition, the caregiver psychological well-being was associated with the coping mechanism, emotional distress, perceived burden and health status of the caregiver (Rodriguez-Perez et al, 2017). The capacity building for BKL was expected to improve the psychological wellbeing of the caregiver by helping them to cope with emotional distress and improving health knowledge related to the dependant elderly.

This study is the first to evaluate Bina Keluarga Lansia (BKL) program in Yogyakarta, using quality of life to measure its impact on the BKL members. The utilization of mix models in the statistical analysis is superior to assess the cluster effect resulted from the sampling method. However, the cross-sectional nature of this study could not warrant a causal relationship between the program, as we did not measure the initial QoL of the members before the program was started.

\section{Conclusion}

This study has shown us the influence of Bina Keluarga Lansia (BKL) program either on the elderly and family members of quality of life, especially in the psychological and social domain. Health education and art/music activities are related to better QoL, thus these activities should be maintained and developed further. This does not necessarily mean that other activities are not important, but the government and the community should review the other activities and produce innovations to further improve the outcome in the BKL members. We believe that this program should be continued with the focus on sustainability and empowering local cultural wisdom to achieve a better quality of life.

\section{References}

Asthana, S., Halter, J. B., High, K. P., Ouslander, J. 
G., Ritchie, C. S., Studenski, S. \& Supiano, M. A. 2017. Hazzard's Geriatric Medicine And Gerontology, 7e. Philadelphia, Mcgraw-Hill.

Badan Koordinasi Keluarga Berencana Nasional. 2011. Bina Keluarga Lansia (Bkl), Jakarta, Bkkbn.

Badan Koordinasi Keluarga Berencana Nasional. 2017. Lansia Tangguh Dengan Tujuh Dimensi, Bahan Penyuluhan Bina Keluarga Lansia, Jakarta, Bkkbn.

Carey, G. E. \& Braunack-Mayer, A. J. 2009. Exploring The Effects Of Government Funding On Community-Based Organizations: 'TopDown' Or 'Bottom-Up' Approaches To Health Promotion? Glob Health Promot, 16, 45-52.

Chaves, L. J. \& Gil, C. A. 2015. Concepções De Idosos Sobre Espiritualidaderelacionada Ao Envelhecimento E Qualidade De Vida. Ciência \& Saúde Coletiva, 20, 3641-3652.

Holahan, C. K., Holahan, C. J., Velasquez, K. E. \& North, R. J. 2008. Longitudinal Change In Happiness During Aging: The Predictive Role Of Positive Expectancies. The International Journal Of Aging And Human Development, 66, 229-241.

Jimenez, M. G., Montorio, I. \& Izal, M. 2017. The Association Of Age, Sense Of Control, Optimism, And Self-Esteem With Emotional Distress. Dev Psychol, 53, 1398-1403.

Katagiri, K. \& Kim, J. H. 2018. Factors Determining The Social Participation Of Older Adults: A Comparison Between Japan And Korea Using Eass 2012. Plos One, 13, E0194703.

Kumar, S. G., Majumdar, A. \& G, P. 2014. Quality Of Life (Qol) And Its Associated Factors Using Whoqol-Bref Among Elderly In Urban Puducherry, India. J Clin Diagn Res, 8, 54-7.

Mendez, M. F., Ala, T. \& Underwood, K. L. 1992.
Development Of Scoring Criteria For The Clock Drawing Task In Alzheimer's Disease. J Am Geriatr Soc, 40, 1095-9.

Pusat Data Dan Informasi Kementerian Kesehatan Republik Indonesia. 2018. Analisis Lansia Di Indonesia. Jakarta: Kementerian Kesehatan Ri.

Robertson, D. A. \& Kenny, R. A. 2016. Negative Perceptions Of Aging Modify The Association Between Frailty And Cognitive Function In Older Adults. Personality And Individual Differences, 100, 120-125.

Rodriguez-Perez, M., Abreu-Sanchez, A., RojasOcana M. J. \& Del-Pino-Casado R. 2017. Coping Strategies And Quality Of Life In Caregivers Of Dependent Elderly Relatives. Health Qual Life Outcomes, 15, 71.

Salomoni, F., Rasi, H. A. \& Hosseinzadeh, S. 2018. Empowering Elderly Iranian Through A Social Group Work Intervention: A Trial Study To Assess The Effect Of The Intervention On Participant's Quality Of Life. Health Soc Care Community, 2018, 1-8.

Smith, J. L. \& Hollinger-Smith, L. 2015. Savoring, Resilience, And Psychological Well-Being In Older Adults. Aging \& Mental Health, 19, 192-200.

Stevens, B. A. 2016. Mindfulness: A Positive Spirituality For Ageing? Australasian Journal On Ageing, 35, 156-158.

World Health Organisation. 1996. Whoqol-Bref: Introduction, Administration, Scoring And Generic Version Of The Assessment. Geneva: World Health Organisation.

Yuliati, A., Baroya, N. M. \& Ririanty, M. 2014. Perbedaan Kualitas Hidup Lansia Yang Tinggal Di Komunitas Dengan Di Pelayanan Sosial Lanjut Usia. E-Jurnal Pustaka Kesehatan, 2, 87-94. 